\title{
LACTATION CURVE AND PHYSIOLOGICAL REACTION FOR EGYPTIAN BUFFALOES UNDER DIFFERENT ENVIRONMENTAL CONDITIONS
}

\author{
FOODA, T. A. and FAYZA I. OMRAN \\ Animal Production Research Institute, ARC, Dokki, Giza \\ (Manuscript received 25 June 2012)
}

\begin{abstract}
The data used in this study were collected from two milking buffalo's farms. These farms are located at different geographical regions, one in the old land (village) and the other in reclaimed land (new land) in Alkobabat village, Atfeh city, Giza governorate. 50 dairy buffalo cows ( $3^{\text {th }}$ and $4^{\text {th }}$ parity), 25 animals in each, the first (farm 1) in the village and the second (farm 2) in the reclaimed land called Abou-Sroor land.

The objective of the present investigation was to describing the lactation curve, calculate the persistency of lactation, total milk yield, daily milk yield and lactation period, and also to study physiological response for buffaloes under environmental conditions in the old land (village) and the reclaimed land.

The results, found that the total milk yield and daily milk were higher in farm 1 than in farm 2 . The daily milk yield ( $\mathrm{kg} /$ day) was higher nearly $1 \mathrm{~kg}$. Farm 2, have salinity in drinking water. The persistency value was higher in farm 2, although short lactation period were observed. Accordingly, buffalo breeding in the reclaimed land give good milk production traits.

Keywords: Lactation curve, total milk yield, lactation period, persistency, physiological parameter, reclaimed land, buffaloes.
\end{abstract}

\section{INTRODUCTION}

Buffaloes the main dairy animals in Egypt. There are nearly 4 million buffaloes, representing $44 \%$ of dairy animals in Egypt (FAOSTAT, 2010), which contribute $44 \%(2,640,638$ ton) of total milk production $(5,960,102$ ton) (FAOSTAT, 2008). Quality-wise, their milk is characterized by exceptionally high fat content and non fat solids percent thus commanding a higher price than cattle milk. Some researchers have characterized milk production curve using a wide variety of statistically estimated equations that regress milk yield per unit time of buffalo cow in a given farm (Wood, 1967, Rook et. al., 1993).

Animal production based on the interplay of animal and environment. High ambient temperature, often coupled with high humidity, these a direct effect on animal, i.e., severely depress of the milk production and reproductive efficiency of 
dairy cattle due to physiological changes including reduced feed intake, increased water intake and evaporative water losses from the body, increased of body temperatures and respiration rate and reduced metabolic rate and maintenance requirements, as well as levels (Spiers et. al., 2004).

The objective of the present investigation was to describing the lactation curve , calculate the persistency of lactation, total milk yield, daily milk yield and lactation period, and also to study physiological response for buffaloes under environmental conditions in the old land (village) and the reclaimed land.

\section{MATERIALS AND METHODS}

\section{Data collection}

The data used in this study were collected from two milking buffalo's farms beginning in the summer. These farms are located at different geographical regions, one in the village and the other in reclaimed land in Alkobabat village, Atfeh city, Giza governorate. 50 dairy buffalo cows ( 3 th and 4th parity), 25 animals in each, the first (farm 1) in the village and the second (farm 2) in the reclaimed land called AbouSroor land.

\section{Feeding and management}

At farm (1), animals feeding depend on concentrate at the milking time.. The Egyptian clovers and Barseem hay were offered adlib in winter, but in summer season, Drawa, Barseem hay and wheat straw were offered adlib. Drinking water twice/day in winter and summer (salinity of water was 200 ppm). Natural matting was performed. The cows are milking twice at the morning and the evening.

The house is one floor, the animals and the family farmer living in the same floor together. Throughout the day, the animals are outside behind the house in agriculture land under shed from maize stoke. The cows are milking inside the house.

At the second farm in the reclaimed land called Abou-Sroor land. Sandy land, they planted olive and Peanut. The animal feeding is depending on concentrate at the milking time. Alfalfa clover, alfalfa hay and bean hulls were offered adlib in the winter, but in summer depend on concentrate at the milking time. Alfalfa clover, Alfalfa hay and bean hulls and wheat straw were offered adlib. The water from wells (salinity $2500 \mathrm{ppm}$ ) the animals were drinking twice/day in winter and 3 times/day in summer. Natural insemination was performed (sire was owned by the farmer). The cows are milking twice at the morning and the evening. 
Animals located within the close yard from clay and the roof from maize stoke above unit of wood. After milking dairy cows get out the house to playground for exercise and return again to inside the house after that.

\section{Physiological response}

Each farm was visited twice a month, to determine, air temperature $\left(A T,{ }^{\circ} \mathrm{C}\right)$ and humidity $(\mathrm{RH}, \%)$ by Mercury centigrade thermometer and hair hygrometer, at the level of 2 meters above the animal under shade (Table1).

Physiological response were record skin temperature $\left(\mathrm{ST},{ }^{\circ} \mathrm{C}\right)$, hair temperature $\left(H T,{ }^{\circ} \mathrm{C}\right)$ by digital thermometer, rectal temperature $\left(\mathrm{RT},{ }^{\circ} \mathrm{C}\right)$ by clinical thermometer and respiration rate (RR/prm) was counted from movements of flank in one minute.

All measured was at 08:00h at the morning. Also the daily milk was weighted for each animal (twice a month) to describe the lactation curve, total milk yield, lactation period and calculated persistency.

Table 1. Means $(\mu)$ and standard errors (SE) of natural air temperature $\left(A T,{ }^{\circ} \mathrm{C}\right)$, relative humidity $(\mathrm{RH}, \%)$ and Temperature-humidity index (THI) at 08:00 $\mathrm{h}$ morning during winter and summer seasons for two farms.

\begin{tabular}{|l|c|c|c|c|c|c|}
\hline \multirow{2}{*}{ Season } & \multicolumn{3}{|c|}{ Farm 1 } & \multicolumn{3}{c|}{ Farm 2 } \\
\cline { 2 - 7 } & $\mathrm{AT},{ }^{\circ} \mathrm{C}$ & $\mathrm{RH}, \%$ & $\mathrm{THI}$ & $\mathrm{AT},{ }^{\circ} \mathrm{C}$ & $\mathrm{RH}, \%$ & $\mathrm{THI}$ \\
\hline Winter & $18.0 \pm 1.7$ & $89.6 \pm 2.6$ & 64.0 & $12.7 \pm 0.9$ & $55.6 \pm 3.3$ & 55.6 \\
\hline Summer & $29.8 \pm 1.5$ & $78.5 \pm 1.7$ & 82.4 & $19.0 \pm 1.6$ & $45.2 \pm 2.5$ & 64.0 \\
\hline
\end{tabular}

Farm1 : Farm in the old land (village)

Farm2 : Farm in the reclaimed land

The data were analyzed using SAS (2002), according to the following model for total milk yield:

$$
Y_{i j k l}=\mu+F_{i}+N_{i j}+S_{k}+(F S)_{i k}+E_{i j k l}
$$

Where: $Y_{i j k l}$ : the observation $i^{\text {th }}$ of the $i^{\text {th }}$ farm in the $j^{\text {th }}$ animal within the $i^{\text {th }}$ farm in the $k^{\text {th }}$ visit season, $\mu$ : overall mean, $F_{i}$ : fixed effect due to the farm (i: 1 farm in the old land (village), 2 farm in the reclaimed land), $N_{i j}$ : fixed effect due to the $j^{\text {th }}$ animal within the $i^{\text {th }}$ farm, $S_{k}$ : fixed effect due to the visit season ( $k: 1$ Winter, 2 Summer), $(F S)_{i k}$ : the interaction between farm and visit season and $E_{i j k l}$ : random error assumed N.I.D. $\left(0, \sigma^{2} e\right)$.

For describing the lactation curve, the logarithmic gamma-type function (Wood, 1967).

$$
\operatorname{Ln}\left(Y_{n}\right)=\operatorname{Ln}(a)+b \operatorname{Ln}(n)-c n
$$

Was used (SAS, 2002), where: 
$\mathrm{Y}_{\mathrm{n}}=$ Total milk yield every 15 day $(\mathrm{kg}), \mathrm{n}=$ Week (s) of lactation, $\mathrm{a}=$ Initial milk yield $(\mathrm{kg}), b=$ Rate $(\mathrm{kg} /$ week) of increase to peak during the ascending phase and $\mathrm{c}=$ Rate $(\mathrm{kg} /$ week) of decrease during the descending phase.

The Persistency $(P, \%)$ have been calculated as the following ratios: $\mathrm{P}=$ ((Milk yield in 28 weeks - Milk yield in first 14 weeks) / Milk yield in first 14 weeks) X 100

The following equation was used to determine the temperature humidity index (THI) as indicator of that combined climatic conditions (Castaneda et. al., 2004).

$$
\mathrm{THI}=(1.8 * \mathrm{~T}+32)-(0.55-0.0055 \mathrm{RH})(1.8 * \mathrm{~T}-26)
$$

Where: $\mathrm{T}$ is air temperature $\left({ }^{\circ} \mathrm{C}\right), \mathrm{RH}$ is the relative humidity $(\%)$.

\section{RESULTS AND DISCUSSION}

Table (2) shows the unadjusted means ( $\mu$ ) and standard errors (SE) for HT, ST, RT and RR of buffalo cows during different seasons in two farms. While Table (4) show the adjusted means and SE for all traits.

Table (3) shows the analysis of variance for HT, ST, RT and RR. The effect of farm and season on all traits was highly significant $(P \leq 0.001)$. But the effect of animal within farm on all traits were not significant $(P>0.05)$ except on HT was high significant $(P \leq 0.001)$. The effect of the interaction between farm and season on all traits were high significant $(P \leq 0.001)$ except on ST was not significant $(P>0.05)$.

The significant effect of farm and season due to animals have a complex of physiological mechanisms which enable them to interact with the environment in various ways to full fill the most successful maintenance and activities. Physiological responses of the ruminant animals towards climatic condition, control of heat dissipation and control of heat production. Maintain internal animal conditions, complementary and adaptation as suggested by Shafie (1989) is a better judgment of adaptation to hot air conditions than considering stability of body temperature.

Shafie and El-Sheikh Aly (1970) found that HT showed equal value to that of AT during summer and autumn, while it was higher than AT in winter but still very low in comparison to that of hot seasons thus the physiological and production condition of animal affect of relationship between heat production from animal and AT.

The interaction between farm and season was not significant for ST, Baumgardt (1969) found that, the relationship between skin temperature and feed intake (FI) thus temperature regulation and FI are linked most clearly through mechanisms of peripheral sensation. 
Table (4) show the least square means (LSM) and SE of HT, ST, RT and RR. All traits in farm 1 were lower than farm 2 . These results may be due to management and mainly feeding in farm 2, the feeding depended on large amount of roughage compared with farm 1 .The close house has bad ventilation and the number of animal per unit area was decreased dispersion by natural way.

The values in summer for all traits were higher than in winter. The physiological mechanisms of the animals always endeavoring to cope with the diurnal and seasonal fluctuations in the environmental conditions. Many authors found increased in value of HT, ST, RT and RR during summer than in winter (Shafie and ElSheik Aly 1970, Omran, 1999 and Ashour et. al., 2004). This the physiological changes occur as response to hot conditions in the digestive system, acid-base chemistry and blood hormones during hot weather and this effect of the production of lactating cow (Kamal et. al., 1989).

Table (5) Shows the daily milk yield (DMY, kg/day) in two seasons, total milk yield (TMY, kg), lactation period (LP), persistency $(P, \%)$, the estimates for $a, b, c$ parameters calculated by the logarithmic gamma-type function and accuracy $\left(R^{2}, \%\right)$ for two farms.

The mean of DMY in farm 1 was higher than farm 2 during winter and summer. The means of TMY and LP in farm 1 were higher than farm 2 . But the persistency in farm 1 was lower than farm 2.

The estimates of the initial milk yield (a) were 51 and $56 \mathrm{~kg}$ in farm 1 and farm 2, respectively. Concerning the rate ( $\mathrm{kg} / \mathrm{two}$ weeks) of increase to peak during the ascending phase (b), the higher rate was $1.32 \mathrm{~kg} / \mathrm{two}$ weeks in farm 1 and lower rate was $0.87 \mathrm{~kg} / \mathrm{two}$ weeks in farm 2 . For the rate $(\mathrm{kg} / \mathrm{two}$ weeks) of decrease during the descending phase (c), farm 1 gave the highest decreasing rate $(-0.25$ $\mathrm{kg} / \mathrm{two}$ weeks), while farm 2 had the lowest decreasing rate $(-0.15 \mathrm{~kg} / \mathrm{two}$ weeks). This clear that, the persistency value was high in farm 2, although decreased of LP and TMY. $R^{2}$ value in farm 1 was higher than in farm 2.

Many authors estimated lactation curve parameters for milk yield of Egyptian buffaloes using the nonlinear form of the incomplete gamma function in the large holder (Sadek et. al., 1998, Aziz et. al., 2003, Mourad et. al., 2005, Aziz et. al., 2006 and Fooda et. al., 2009).

To maintain the stability of body temperature the animal within normal (38.3$38.7^{\circ} \mathrm{C}$ ) to need the increase heat loss and reduce the endogenous heat production. Several physiological changes indicate the response of dairy cows to heat which is manifested by number of overt reactions, including reduced feed intake, increased water intake and evaporative water losses from the body, increased RR and 
maintenance requirement as well as altered endocrine parameters. The sudden responses of cattle are an increase in water intake and RR a reduction of feed intake and subsequently, a reduction of metabolic rate (Calamari et. al., 2007).

Cows exhibit, reduced feed intake and decreased activity as well as increased respiratory rate and increase in both peripheral blood flow and sweating, these responses have deleterious effect on both production and physiological status of the cow (West, 2003). This is explain the decreased of values of milk yield in farm 2 in comparative with farm 1 and increased the value of physiological parameters in farm 2 than in farm 1.

Fooda et al. (2009) found that the persistency in the upper Egypt was $80 \%$ in Sids Farm in Bani Sweef governorate, the location of farm under this study was near Bani Sweef governorate (the end of Giza governorate which following that Bani Sweef governorate). In the present study the values of persistency were 83 and $89 \%$ in farm 1 and farm 2, respectively.

As shown in Table 5, weeks to peak production (beginning of the peak) estimated by gamma function were 8 weeks for the two farms. This was equal to the same week observed for the actual data. The same situation was observed in the case of week no. of end peak, since this was 12 weeks in farm 1 and 14 weeks in farm 2 and this in the case of actual data and the estimates of gamma function.

As observed in Table 6 for both actual data and estimates of gamma function, farm $1(P=83 \%)$ was 5 weeks in the peak production which was the shortest period than farm 2 was 7 weeks ( $P=89 \%$ ). These results may be ability of buffalo cows under harsh of condition in the reclaimed land to more adapted to change of air temperature (AT, ${ }^{\circ} \mathrm{C}$ ) and relative humidity $(\mathrm{RH}, \%)$. Without large change of physiological performance the animal can be maintenance of persistency a long time in farm 2 comparative with farm 1 . Although increased of total milk yield in farm 1 , the different between two farms $1 \mathrm{~kg} /$ day nearly.

Fig. (1) show the lactation curve of buffalo cows calving in the two farms, the lactation curve in village farm the values of initial milk yield $(51 \mathrm{~kg})$ was lower than in reclaimed land farm $(56 \mathrm{~kg})$. While higher value for the rate of increase to peak during the ascending phase in village farm $1.32 \mathrm{~kg} /$ two weeks comparative with farm 2 was $0.87 \mathrm{~kg} /$ two weeks and decrease during the descending phase in farm $1(-0.25$ $\mathrm{kg} / \mathrm{two}$ weeks) was higher comparative with farm2 (-0.15 kg/two weeks). 


\section{CONCLUSION}

The farm 1 in old land (village) was better for milk production traits and physiological responses than farm 2 (reclaimed land). Also the buffalo cows can be live in the reclaimed land under harsh conditions. In spite of this conditions, the average daily milk less $1 \mathrm{~kg}$ only with increasing the persistence. The close house from clay and roof from maize stoke above unit of wood give appropriate THI for physiological performance and production for buffalo cows in the reclaimed land. Accordingly, buffalo breeding in the reclaimed land give good milk production traits.

Table 2. Unadjusted means $(\mu)$ and standard errors (SE) hair temperature $\left(H T,{ }^{\circ} \mathrm{C}\right)$, skin temperature $\left(\mathrm{ST},{ }^{\circ} \mathrm{C}\right)$, rectal temperature $\left(\mathrm{RT},{ }^{\circ} \mathrm{C}\right)$ and respiration rate $(\mathrm{RR} / \mathrm{prm})$ at different seasons in two farms.

\begin{tabular}{|c|c|c|c|c|}
\hline \multirow{2}{*}{ Trait } & \multicolumn{2}{|c|}{ Winter } & \multicolumn{2}{c|}{ Summer } \\
\cline { 2 - 5 } & Farm 1 & Farm 2 & Farm 1 & Farm 2 \\
\hline HT & $28.74 \pm 0.19$ & $31.27 \pm 0.11$ & $32.25 \pm 0.09$ & $34.05 \pm 0.04$ \\
ST & $33.44 \pm 0.04$ & $34.85 \pm 0.02$ & $34.37 \pm 0.03$ & $35.87 \pm 0.02$ \\
RT & $37.20 \pm 0.02$ & $37.17 \pm 0.02$ & $38.11 \pm 0.02$ & $39.20 \pm 0.07$ \\
RR & $19.7 \pm 0.08$ & $22.29 \pm 0.17$ & $24.04 \pm 0.14$ & $34.88 \pm 1.64$ \\
\hline
\end{tabular}

Farm1 : Farm in the old land (village)

Farm2 : Farm in the reclaimed land

Table 3. Analysis of variance for hair temperature $\left(\mathrm{HT},{ }^{\circ} \mathrm{C}\right)$, skin temperature $\left(\mathrm{ST},{ }^{\circ} \mathrm{C}\right)$, rectal temperature $\left(R T,{ }^{\circ} \mathrm{C}\right)$ and respiration rate $(\mathrm{RR} / \mathrm{prm})$.

\begin{tabular}{|l|c|c|c|c|c|}
\hline \multirow{2}{*}{$\begin{array}{c}\text { Source of } \\
\text { variation }\end{array}$} & \multirow{2}{*}{$\mathrm{df}$} & $\mathrm{HT}$ & $\mathrm{ST}$ & $\mathrm{RT}$ & $\mathrm{RR}$ \\
\cline { 3 - 6 } & 48 & $13.81 * * *$ & $0.16 \mathrm{~ns}$ & $0.07 \mathrm{~ns}$ & $109 \mathrm{~ns}$ \\
\hline Farm - Animal & 1 & $876.62 * * *$ & $394.20 * * *$ & $52.49 * * *$ & $9216.89 * * *$ \\
Farm (F) & 1 & $1832.18 * * *$ & $177.06 * * *$ & $402.39 * * *$ & $14374.74 * * *$ \\
Season (S) & & & & & \\
Interaction : & 1 & $24.19 * * *$ & $0.33 \mathrm{~ns}$ & $58.06 * * *$ & $2709.21 * * *$ \\
F*S & 696 & 1.64 & 0.16 & 0.27 & 115.99 \\
\hline
\end{tabular}

$* * *: \mathrm{P}<0.001$

ns : Not significant $(P>0.05)$. 
Table 4. Least square means (LSM) and standard errors (SE) for hair temperature $\left(\mathrm{HT},{ }^{\circ} \mathrm{C}\right)$, skin temperature $\left(\mathrm{ST},{ }^{\circ} \mathrm{C}\right)$, rectal temperature $\left(\mathrm{RT},{ }^{\circ} \mathrm{C}\right)$ and respiration rate $(\mathrm{RR} / \mathrm{prm})$.

\begin{tabular}{|l|c|c|c|c|}
\hline \multirow{2}{*}{ Main Effect } & \multicolumn{4}{|c|}{ LSM \pm SE } \\
\cline { 2 - 5 } & HT & ST & RT & RR \\
\hline Farms : & & & & \\
Farm 1 & $30.49 \pm 0.07$ & $33.90 \pm 0.02$ & $37.66 \pm 0.03$ & $21.56 \pm 0.56$ \\
Farm2 & $32.66 \pm 0.07$ & $35.36 \pm 0.02$ & $38.19 \pm 0.03$ & $28.58 \pm 0.56$ \\
Season: & & & & \\
Winter & $30.01 \pm 0.07$ & $34.14 \pm 0.02$ & $37.19 \pm 0.03$ & $20.68 \pm 0.58$ \\
Summer & $33.14 \pm 0.06$ & $35.12 \pm 0.02$ & $38.65 \pm 0.03$ & $29.46 \pm 0.54$ \\
\hline
\end{tabular}

Farm1 : Farm in the old land (village)

Farm2 : Farm in the reclaimed land

Table 5. Daily milk yield (kg/day) at different seasons, total milk yield (TMY), lactation period (LP), persistency $(\mathrm{P}, \%)$ and estimates the parameters of the Wood's model for milk yield in two farms.

\begin{tabular}{|c|c|c|}
\hline Trait & Farm1 & Farm2 \\
\hline Daily milk yield (kg/day) & & $7.1 \pm 0.09$ \\
Winter & $8.3 \pm 0.18$ & $7.2 \pm 0.14$ \\
Summer & $8.1 \pm 0.21$ & \\
Total milk yield (TMY, kg) & & $1339 \pm 12.6$ \\
Lactation period (LP, day) & $1586 \pm 18.8$ & $188 \pm 1.95$ \\
& $194 \pm 0.83$ & \\
Persistency (P, \%) & & 89 \\
& & \\
Parameters: & & \\
a $\pm S E(k g)$ & $51 \pm 1.03$ & $56 \pm 1.03$ \\
$\mathrm{~b} \pm \mathrm{SE}(\mathrm{kg})$ & $1.32 \pm 0.04$ & $0.87 \pm 0.04$ \\
$\mathrm{C} \pm \mathrm{SE}(\mathrm{kg})$ & $-0.25 \pm 0.008$ & $-0.15 \pm 0.007$ \\
Accuracy $\left(\mathrm{R}^{2}, \%\right)$ & 77 & 58 \\
\hline
\end{tabular}

Farm1 : Farm in the old land (village)

Farm2 : Farm in the reclaimed land 
Table 6. Weeks to peak yield and peak yield $(\mathrm{kg})$ estimated by gamma function in comparison with actual yield for Egyptian buffaloes.

\begin{tabular}{|c|c|c|c|c|c|c|c|c|}
\hline \multirow{2}{*}{ Farm } & \multicolumn{4}{|c|}{ The actual milk yield } & \multicolumn{4}{c|}{ After use gamma function } \\
\cline { 2 - 9 } & Beginning peak & \multicolumn{2}{c|}{ End peak } & \multicolumn{2}{c|}{ Beginning peak } & \multicolumn{2}{c|}{ End peak } \\
\cline { 2 - 9 } & Week & Milk $(\mathrm{kg})$ & Week & Milk $(\mathrm{kg})$ & Week & Milk (kg) & Week & Milk (kg) \\
\hline \multirow{2}{*}{ Farm 1 } & 8 & 142.5 & 12 & 127.5 & 8 & 153 & 12 & 160 \\
\hline Farm 2 & 8 & 120 & 14 & 112.5 & 8 & 119 & 14 & 123 \\
\hline
\end{tabular}

Farm1 : Farm in the old land (village)

Farm2 : Farm in the reclaimed land

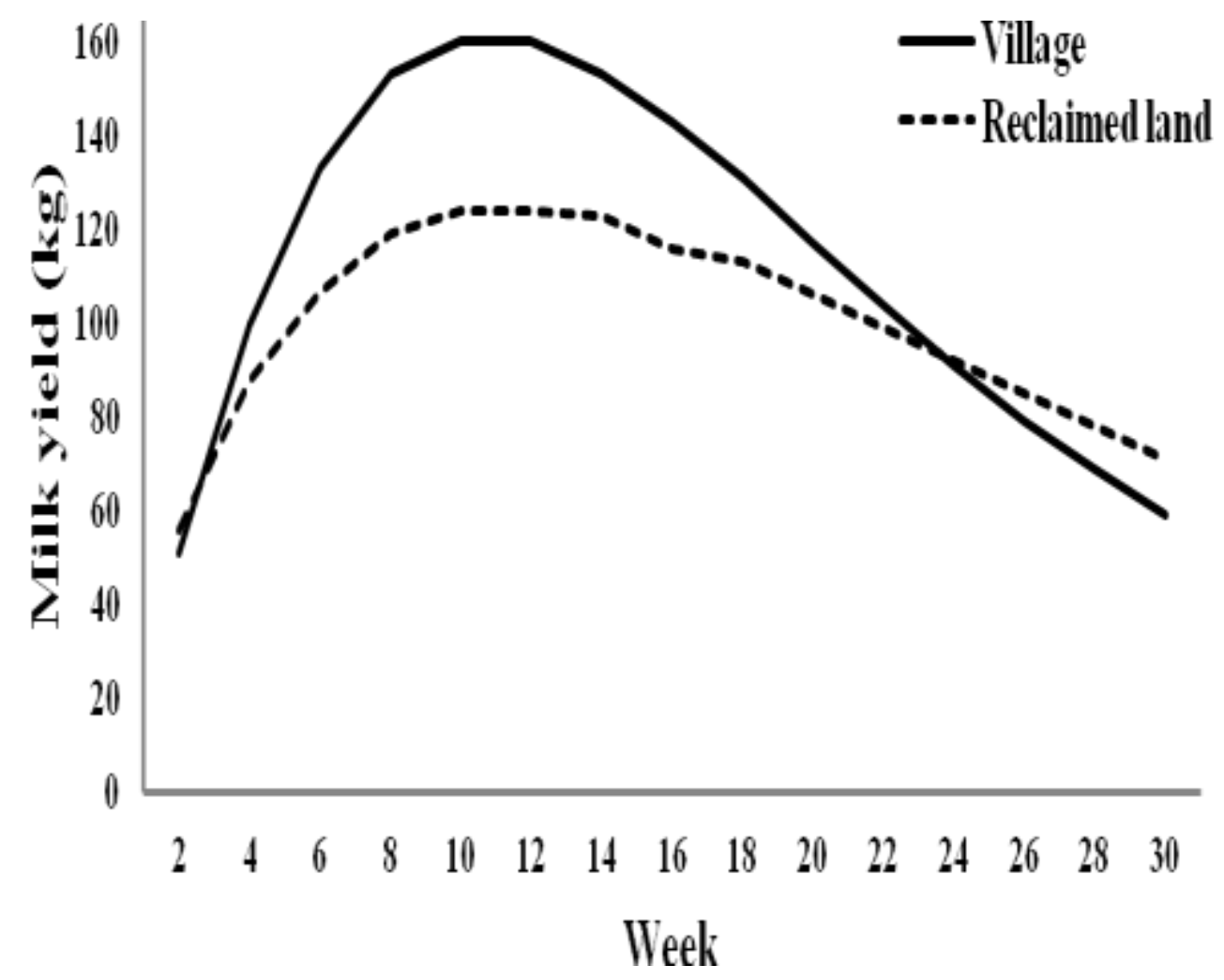

Fig. 1 . Lactation curve for buffalo cows calving in two farms. 


\section{REFERENCES}

1. Ashour, G., L. R. Hassan, F. I. Omran and M. M. Shafie. 2004. Thermorespiratory responses, hematological and hormonal reactions of buffalo and Friesian calves to the rise in environmental temperature. Egyptian J. Anim. Prod., 41 (Suppl. Issue), 353.

2. Aziz M A, A. E. Mahdy, O. M. El-Shafie and N. A. Shalaby. 2003. A comparison of different models of the lactation curve in Egyptian buffaloes. J. Agric. Sci., Mansoura Univ. 28(7): 5253-5268.

3. Aziz M A, N. A. Shalaby, O. M. El-Shafie, A. T. Mahdy and A. Nishida. 2006. Comparison between the shapes of lactation curve of Egyptian buffalo milk yield estimated by the incomplete gamma function and a new model. Livestock Research for Rural Development 18 (5).

4. Baumgardt, B. R. 1969. Voluntary feed intake. In: Animal Growth and Nutrition. E.S.E. Hafez and I. A. Dyer (eds.). Lea and Febiger Philadelphia, USA, pp. 121137.

5. Calamari, L., F. Abeni, F. Calegari and L. Stefanini. 2007. Metabolic conditions of lactating Friesian dairy cows during the hot season in the Po valley. 2. Blood minerals and acid-base chemistry. Int. J. Biometeorol, 52: 97-107.

6. Castaneda, C. A., J. B. Gaughan and Y. Sakaguchi. 2004. Relationships between climatic conditions and the behavior of feedlot cattle. Anim. Prod. Aust., 25: 3336.

7. FAOSTAT. 2008. FAO Statistics Division. Fao, Rome, Italy.

8. FAOSTAT. 2010. FAO Statistics Division. Fao, Rome, Italy.

9. Fooda, T. A., I. A. Gebreel and Hoda M. Abd El-Raoof. 2009. Study the change of lactation curve in Egyptian buffaloes. Egypt. J. Appl. Sci., 24(10B) : 410-417.

10. Kamal, T. H., A. A. Habeeb, A. M. Abdel-Samee and I. F. Marai. 1989. Milk production of heat-stressed Friesian cows and its improvement in the subtropics. Proc. Inter. Symp., 5-7 Nov. 1988, Cairo, Egypt, Pudoc Scientific Publishers, Wageningen, The Netherland, EAAP Publication, No. 38: 156-158.

11. Mourad, Kawthar A., T. A. Fooda, Karima A. Shahin and A. A. Ashmawy. 2005. Lactation curve, milk production and days open in Egyptian buffaloes. (Bubalus bubalis), J. Buffalo Sci. and Techniq., 1, Anno XI, Marzo, Italy, 72-80.

12. Omran, Fayza I. 1999. Physiological reaction and growth performance of buffaloes and Friesian calves to heat stress. M. Sc. Thesis, Fac. Agric., Cairo Univ., Giza, Egypt, 147P. 
13. Rook A J, F. France and M. S. Dhanoa. 1993. On the mathematical description of lactation curves. J. Agric. Sci., (Cambridge) 121: 97-102.

14. Sadek, R. R., M. M. Mohamed, M. A. M. Ibrahim and H. M. A. Abdel-Lattef. 1998. Estimation of lactation curve parameters in Egyptian buffaloes. Egyptian J. Anim. Prod., 35: 1-27.

15. SAS. 2002. Statistical Analysis System Institute, Inc., Cary, Nc., USA.

16. Shafie, M. M. 1989. Environmental constraints on animal productivity. Proc. Inter. Symp., 5-7 Nov. 1988, Cairo, Egypt, Pudoc Scientific Publishers, Wageningen, The Netherland, EAAP Publication, No. 38: 10-16.

17. Shafie, M. M. and L. El-Sheikh Aly. 1970. Heat tolerance of Friesian cattle under Egyptian climatic conditions. Egyptian J. Anim. Prod., 10 : 99.

18. Spiers, D. F., J. N. Spain, J. D. Samson and R. P. Rhoads. 2004. Use of physiological parameters to predict milk yield and feed intake in heat-stressed dairy cows.

19. West, J. W. 2003. Effects of heat-stress on production in dairy cattle. J. Dairy Sci., 86: 2131.

20. Wood, P. D. P. 1967. Algebraic model of the lactation curve in cattle. Nature, 216: 164-165. 


\title{
منحني الحليب ورد الفعل الفسيولوجي للجاموس المصري تحث الظروف البيئية المختلفة
}

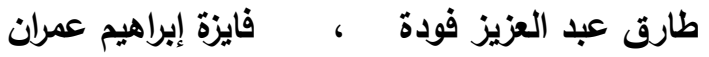 \\ معهُ بحوث الإنتاج الحيواني - قسم بحوث تربية الجاموس - الدقي - جيزة - مصر
}

إجريت هذه الدراسة في مزرعنين جاموس لإنتاج اللبن في قرية القبابات، مدينة أطفيح

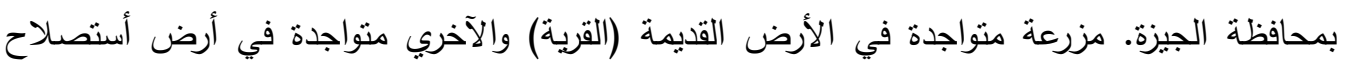

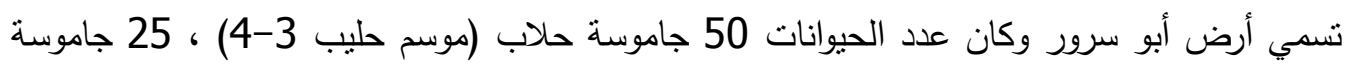
حلاب بكل مزرعة.

الهذف من هذه الدراسة هو وصف منحني اللبن وكذلك تقدير المثابرة لإنتاج اللبن في الجاموس والإنتاج اليومي للبن والإنتاج اللبن الكلي وطول فترة الحليب ودراسة رد الفعل الفسيولوجي تحت ظروف القرية وأرض الإسنصلاح).

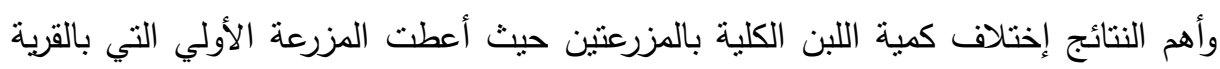

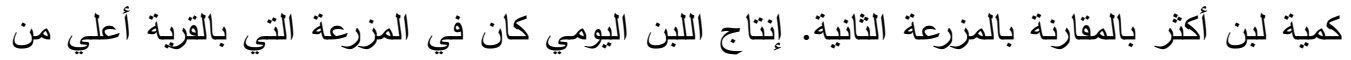

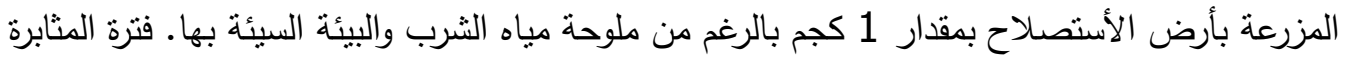

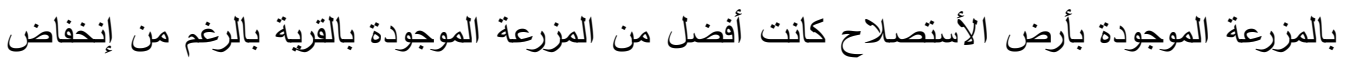

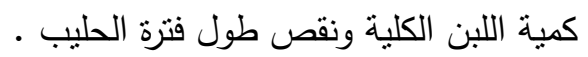
مما سبق نوصي المربي في مناطق الإستصلاح بمراعاة المسكن من حيث الإرتفاع والتهوية وعدد الحيوانات داخل المسكن بمسافات مناسبة بين الحيوانات ربما يصل لنفس الإنتاج في المزرعة لإنة المتواجدة بالقرية حيث يعوض الحرارة العالية في الأراضي الصحراروية إنخفاض معدل الرطوبة النسبية

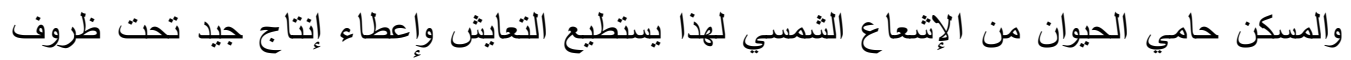

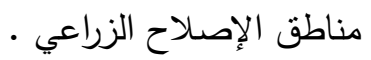

